\title{
KONSEP-KONSEP TENTANG GENDER PERSPEKTIF ISLAM
}

\author{
Maslamah dan Suprapti Muzani \\ Pegiat Gender dan Anak Indramayu Jawa Barat \\ email: suprazani@yahoo.com
}

\begin{abstract}
Abstrak
Islam selalu menempatkan semua hal pada posisi yang seimbang. Islam juga menempatkan Laki-laki dan perempuan sebagai manusia yang memiliki posisi seimbang dan sama. Meskipun demikian, masih banyak anggapan membedakan peran dan kedudukan laki-laki dan perempuan. Faktor penyebab pembedaan kedudukan ini diantaranya adanya kesalahan pemahaman dalam mengkonstruksi peran sosial antara laki-laki dan perempuan sebagai akibat dari interpretasi teks suci alQur'an secara particular dn terkesan tidak utuh. Hal ini tentu mengakibatkan terjadinya konsepsi-konsepsi yang tidak seimbang dalam menempatkan posisi laki-laki dan perempuan dalam kehidupan masyarakat. Islam telah meletakkan dasar filosofis dan argumentative dalam menempatkan kedudukan laki-laki dan perempuan secara seimbang. Oleh karenanya, meletakkan kedudukan laki-laki dan perempuan secara seimbang sesuai dengan kadar keimanan dan ketakwaan menjadi salah satu upaya jalan tengah yang harus ditempuh para Muslim dan Muslimat.
\end{abstract}

Kata Kunci: bias gender, Islam

\section{A. Pendahuluan}

Di dalam ayat-ayat al-Qur'an maupun Sunnah Nabi yang merupakan sumber utama ajaran Islam, terkandung nilai-nilai universal yang menjadi petunjuk bagi kehidupan manusia dulu, kini dan akan datang. Nilai-nilai tersebut antara lain nilai kemanusiaan, keadilan, kemerdekaan, kesetaraan dan sebagainya. Berkaitan dengan nilai keadilan dan kesetaraan, Islam tidak pernah mentolerir adanya perbedaan atau perlakuan diskriminasi di antara 
umat manusia. ${ }^{1}$ Bicara soal perempuan, kita akan diarahkan lebih dulu untuk melihat pandangan al-Qur'an tentang kejadiannya. Sebab, dari arah inilah klaim-klaim, baik yang berada positif dan atau negatif, tentang perempuan muncul. Secara kronologis, asal-usul kejadian manusia tidak dijelaskan oleh al-Qur'an. ${ }^{2}$

Pandangan umum menyatakan bahwa Islam secara tidak langsung telah merendahkan kaum perempuan. ${ }^{3}$ Sebagaimana yang telah dijelaskan dalam pasal 1 bahwa manusia dilahirkan sederajat dan bebas sesuai yang dinyatakan atau disimpulkan oleh al-Qur'an surat al-Hujurat ayat 13 bahwa lelaki dan wanita sama derajatnya dalam hak dan tanggung jawabnya sebagai manusia ciptaan Tuhan. dan dalam kehidupan sosial pun pria dan wanita mempunyai hak yang sama. Hanya saja peranannya yang berbeda sesuai dengan kodrat yang telah dimiliki masing-masing. ${ }^{4}$

\section{B. Konsep Bias Genderdalam Teks Keagamaan}

Gender adalah pandangan atau keyakinan yang dibentuk masyarakat tentang bagaimana seharusnya seorang perempuan atau laki-laki bertingkah laku maupun berpikir. Misalnya: pandangan bahwa perempuan ideal harus pandai memasak, pandai merawat diri, lemah lembut, atau keyakinan bahwa perempuan adalah makhluk sensitif, emosional, selalu memakai perasaan. Sebaliknya seorang laki-laki sering dilukiskan berjiwa pemimpin, pelindung, kepala rumah tangga, rasional, tegas dan sebagainya. Dengan singkat gender secara jenis kelamin sosial yang dibuat masyarakat, yang belum tentu benar. Dalam surat al-Isra ayat 70:

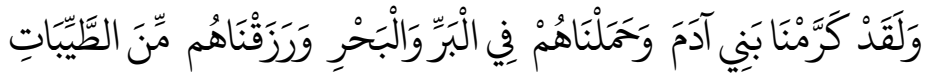

${ }^{1} \mathrm{Hj}$. Mursyidah Thahir (ed.), Pemikiran Islam tentang Pemberdayaan Perempuan, (Jakarta: PP Muslimat NU Kerjasama dengan Logos Wacana Ilmu, 2000), hlm. 21.

${ }^{2}$ Islah Gusmian, Khazanah Tafsir Indonesia dan Hermeneutika Hingga Ideologi, (Jakarta: Teraju, 2003), hlm. 303.

${ }^{3}$ Margaret Smith, M.A., P.Hd., Rabiah Pergulatan Spiitual Perempuan, (Surabaya: Risalah Gusti, 1997), hlm. 127.

${ }^{4}$ Baharuddin Lopa, Al-Qur'an dan Hak-hak Asasi Manusia, (Yogyakarta: Dana Bhakti Prima Yasa, 1996), hlm. 66. 


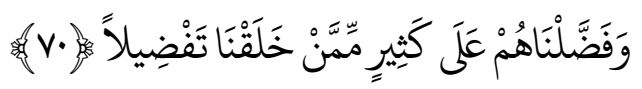

"Dan sesungguhnya telah Kami muliakan anak-anak Adam, Kami angkut mereka di daratan dan di lautan, Kami beri mereka rezki dari yang baik-baik dan Kami lebihkan mereka dengan kelebihan yang sempurna atas kebanyakan makhluk yang telah Kami ciptakan." (QS. al-Isra [17]: 70)

Bahwa Allah telah menciptakan laki-laki dan perempuan dengan bentuk yang terbaik dengan kedudukan yang paling hormat. Manusia juga diciptakan mulia dengan memiliki akal, perasaan dan menerima petunjuk. Oleh karena itu al Qur'an tidak mengenal pembedaan antara laki-laki dan perempuan, karena di hadapan Allah adalah sama. Laki-laki dan perempuan mempunyai derajat dan kedudukan yang sama, dan yang membedakan antara laki-laki dan perempuan hanyalah dari segi biologisnya. ${ }^{5}$

Namun, di beberapa bagian kehidupan sosial seringkali masih dibedakan, yang sering dalam pemberian hak diutamakan pihak pria. Itulah sebabnya lahir pergerakan emansipasi wanita yang berhasil menjamin persamaan hak tersebut. UDHR telah menjamin hak wanita sederajat dengan pria tanpa diskriminasi, dan negara-negara OKI menjamin pula hak wanita sederajat dengan pria terlihat pada pasal 6 yang bunyinya:

1. Wanita memiliki hak yang sama dengan pria dalam mempertahankan derajat kemanusiaannya dan memiliki hak-hak untuk menikmati hak persamaan tersebut di samping melaksanakan kewajiban-kewajibannya, memiliki hak sipil dan kebebasan yang berhubungan dengan keuangan dan hak untuk menjaga nama baik pribadi dan keturunannya.

2. Suami bertanggung jawab untuk memberikan nafkah dan kesejahteraan kepada keluarganya.

Pasal 6 menunjukkan bahwa wanita sama derajatnya dengan pria dan berhak menikmati hidup sesuai tugas dan penampilannya sebagai wanita. Wanita juga mempunyai hak sipil seperti pria, misalnya: mencari ilmu,

\footnotetext{
${ }^{5}$ Nasaruddin Umar, Qur'an untuk Perempuan, (Jakarta: Jaringan Islam Liberal (JIL) dan Teater Utan Kayu, 2002), hlm. 27.
} 
bekerja dan sebagainya. Ia juga mempunyai hak yang sama untuk menjaga nama baiknya sampai ia meninggal. Perihal wanita yang sederajat dengan pria sesuai derajat kemanusiaannya, telah dijelaskan dalam al-Qur'an dalam surat al-Nisa' ayat 32 dan 34. Ayat-ayat tersebut menunjukkan bahwa dalam statusnya sebagai manusia sama derajatnya di mata Tuhan. sehingga dalam kehidupan berkeluarga suami memimpin istri dijelaskan dalam surat an-Nisa' ayat 34, sedangkan hak istri terhadap suaminya dijelaskan dalam surat al-Baqarah ayat 228 , yang bunyinya:

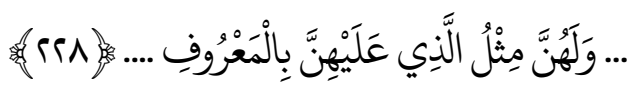

"Dan para wanita mempunyai hak yang seimbang dengan kewajibannya menurut cara yang ma'ruf" (QS. al-Baqarah [2]: 228). ${ }^{6}$

Adapun dalil-dalil al-Qur'an yang mengatur tentang kesetaraan gender adalah:

1. Tentang hakikat penciptaan laki-laki dan perempuan

Surat al-Rum ayat 21, surat an-Nisa' ayat 1, surat al-Hujurat ayat 13 yang intinya berisi bahwa Allah SWT telah menciptakan manusia berpasang-pasangan yaitu laki-laki dan perempuan, supaya mereka hidup tenang dan tentram, agar saling mencintai dan menyayangi serta kasih dan mengasihi, agar lahir dan menyebar banyak laki-laki dan perempuan serta agar mereka saling mengenal. Ayat-ayat di atas menunjukkan adanya hubungan yang saling timbal balik antara lelaki dan perempuan, dan tidak ada satupun yang mengindikasikan adanya superioritas satu jenis atas jenis lainnya.

2. Tentang kedudukan dan kesetaraan antara laki-laki dan perempuan Surat Ali Imran ayat 195, surat an-Nisa' ayat 124, surat an-Nahl ayat 97, surat at-Taubat ayat 71-72, surat al-Ahzab ayat 35. Ayat-ayat tersebut memuat bahwa Allah SWT secara khusus menunjuk baik kepada perempuan maupun laki-laki untuk menegakkan nilai-nilai Islam dengan beriman, bertaqwa dan beramal. Allah SWT juga memberikan peran dan tanggung jawab yang sama antara laki-laki dan

${ }^{6}$ Baharuddin Lopa, Al-Qur'an dan Hak-hak Asasi Manusia, hlm. 66-67. 
perempuan dalam menjalankan kehidupan spiritualnya. Dan Allahpun memberikan sanksi yang sama terhadap perempuan dan laki-laki untuk semua kesalahan yang dilakukannya. Jadi intinya kedudukan dan derajat antara laki-laki dan perempuan di mata Allah SWT adalah sama, dan yang membuatnya tidak sama hanyalah keimanan dan ketaqwaannya. $^{?}$

Sedangkan gender dalam al-Qur'an menurut Dr. Nasaruddin Umar dalam Jumal Pemikiran Islam tentang Pemberdayaan Perempuan (2000) ada beberapa hal yang menunjukkan bahwa prinsip-prinsip kesetaraan gender ada di dalam al-Qur'an, yaitu:

1. Perempuan dan laki-laki sama-sama sebagai hamba menurut QS. alDzariyat [51]: 56. Dalam kapasitas sebagai hamba tidak ada perbedaan antara laki-laki dan perempuan. Keduanya mempunyai potensi dan peluang yang sama untuk menjadi hamba ideal dalam al-Qur'an bisa diistilahkan sebagai orang-orang yang bertaqwa (muttaqin), dan untuk mencapai derajat muttaqin ini tidak dikenal adanya perbedaan jenis kelamin, suku bangsa atau kelompok etnis tertentu, sebagaimana disebutkan dalam QS. Al-Hujurat [49]: 13.

2. Perempuan dan laki-laki sebagai khalifah di bumi kapasitas manusia sebagai khalifah di muka bumi (khalifah fil al 'ard) ditegaskan dalam QS. al-An'am [6]: 165) dan dalam QS. al-Baqarah [2]: 30. Dalam kedua ayat tersebut, kata "khalifah" tidak menunjuk pada salah satu jenis kelamin tertentu, artinya baik perempuan maupun laki-laki mempunyai fungsi yang sama sebagai khalifah, yang akan mempertanggungjawabkan tugas-tugas kekhalifahannya di bumi.

3. Perempuan dan laki-laki menerima perjanjian awal dengan Tuhan. Perempuan dan laki-laki sama-sama mengemban amanah dan menerima perjanjian awal dengan Tuhan, seperti dalam QS. al-A'raf [7]: 172, yakni ikrar akan keberadaan Tuhan yang disaksikan oleh para malaikat. Sejak awal sejarah manusia dalam Islam tidak dikenal adanya diskriminasi jenis kelamin. Laki-laki dan perempuan samasama menyatakan ikrar ketuhanan yang sama. Qur'an juga menegas-

${ }^{7}$ Nasaruddin Umar, Qur'an untuk Perempuan, hlm. 27. 
kan bahwa allah memuliakan seluruh anak cucu Adam tanpa pembedaan jenis kelamin. (QS. al-Isra' [17]: 70).

4. Adam dan Hawa terlibat secara aktif dalam drama kosmis semua ayat yang menceritakan tentang drama kosmis, yakni cerita tentang keadaan Adam dan Hawa di surga sampai keluar ke bumi, selalu menekankan keterlibatan keduanya secara aktif, dengan penggunaan kata ganti untuk dua orang (humā), yakni kata ganti untuk Adam dan Hawa.

5. Perempuan dan laki-laki sama-sama berpotensi meraih prestasi maksimum tidak ada pembedaan antara laki-laki dan perempuan, ditegaskan secara khusus dalam tiga ayat, yakni Ali Imran 195, al- Nisa' 124, alNahl 97. Ketiganya mengisyaratkan konsep kesetaraan gender yang ideal dan memberikan ketegasan bahwa prestasi individual, baik dalam bidang spiritual maupun karier profesional, tidak mesti didominasi oleh satu jenis kelamin saja. ${ }^{8}$

Munculnya ketidakadilan terhadap perempuan dengan dalih agama disebabkan karena adanya implementasi yang salah satu dari ajaran agama tersebut yang disebabkan oleh pengaruh faktor sejarah, lingkungan budaya dan tradisi yang patriarkhi di dalam masyarakat, sehingga menimbulkan sikap dan perilaku individual yang secara turun temurun menentukan status kaum perempuan dan ketimpangan gender tersebut. Hal inilah yang kemudian menimbulkan mitos-mitos salah yang disebarkan melalui nilai-nilai dan tafsir-tafsir ajaran agama yang keliru mengenai keunggulan kaum lelaki dan melemahkan kaum perempuan.

Adapun pandangan dasar atau mitos-mitos yang menyebabkan munculnya ketidakadilan terhadap perempuan adalah:

1. Keyakinan bahwa perempuan diciptakan dari tulang rusuk laki-laki, sehingga perempuan dianggap sebagai makhluk kedua yang tidak akan mungkin ada tanpa kehadiran laki-laki. Karena keberadaan perempuan hanya dianggap sebagai pelengkap dan diciptakan hanya untuk tunduk di bawah kekuasaan laki-laki.

${ }^{8}$ Lily Zakiyah Munir, Memposisikan Kodrat Perempuan dan Perubahan dalam Perspektif Islam, 2002, hlm. 75 . 
2. Keyakinan bahwa perempuan sebagai sumber dari terusirnya manusia (laki-laki) dari surga, sehingga perempuan dipandang dengan rasa benci, curiga, jijik, bahkan lebih jauh lagi perempuan dianggap sebagai sumber malapetaka.

Al-Qur'an tidak mengajarkan diskriminasi antara lelaki dan perempuan sebagai manusia. di hadapan Allah lelaki dan perempuan mempunyai derajat dan kedudukan yang sama. Oleh karena itu pandangan-pandangan yang menyudutkan posisi perempuan sudah selayaknya diubah, karena al Qur'an selalu menyerukan keadilan, keamanan dan ketenteraman, mengutamakan kebaikan dan mencegah kejahatan. Ayat-ayat inilah yang digunakan maqasid al Syari'ah atau tujuan-tujuan utama syari'at. Jika tidak ada penafsiran yang tidak sejalan dengan prinsip-prinsip keadilan dan hak asasi manusia, maka penafsiran itu harus ditinjau kembali.

Secara kronologis, asal usul kejadian manusia tidak dijelaskan oleh al Qur'an. Cerita penciptaan manusia, banyak diketahui melalui hadits, kisah israilliyat dan riwayat yang bersumber dari kitab Taurat, Injil, dan Talmud. Substansi asal usul kejadian Adam dan Hawa juga tidak dibedakan secara tegas. Memang ada isyarat bahwa Adam diciptakan dari tanah kemudian dari tulang rusuk Adam diciptakan Hawa, namun isyarat ini diperoleh dari hadits-hadits. Kata hawa yang selama ini dipersepsikan sebagai perempuan yang menjadi istri Adam sama sekali tidak pernah disinggung dalam al Qur'an. Bahkan, klaim bahwa adam sebagai manusia pertama dan berjenis kelamin laki-laki masih dipertemukan oleh beberapa kalangan.

\section{Konstruk Sosial dan Watak Agama}

Mendudukkan perempuan pada tempat semestinya seperti sama halnya dengan membongkar habis sejarah manusia yang telah berlangsung berabad-abad, yang digugat tak hanya sistem sosial yang terdiri dari kaum pria, tapi juga kaum perempuan itu sendiri. Selain itu realitas sosial yang ada seringkali menjadikan dalil-dalil agama sebagai dasar untuk menolak keadilan gender. Kitab-kitab tafsir dijadikan melegalkan pola hidup patriarkhi yang memberikan hak-hak istimewa kepada pria dan cenderung memojok-

${ }^{9}$ Hj. Mursyidah Thahir (ed.), Pemikiran Islam tentang Pemberdayaan Perempuan, hlm. 35. 
kan perempuan, pria dianggap sebagai jenis kelamin utama dan perempuan sebagai jenis kelamin kedua.

Pemahaman agama seperti ini mengendap di alam bawah sadar perempuan dan berlangsung sedemikian lama, sehingga melahirkan kesan seolah perempuan memang tidak pantas sejajar dengan pria dan membentuk etos kerja yang timpang antara kedua jenis hamba Tuhan tersebut. Suarasuara untuk merekonstruksi tafsir atas ayat yang mengenai wilayah perempuan ini untuk kesekian kalinya kembali terdengar lewat seminar nasional bertajuk "Bias Gender dalam Penafsiran al-Qur'an" yang diselenggarakan oleh Pusat Studi Wanita Universitas Negeri Jakarta di Hotel Indonesia Selasa (28/5). Menurut pakar kajian gender Nasaruddin Umar, masalah keadilan selama ini cenderung mengeliminir persoalan asasnya. Selama ini katanya kita lebih banyak menyoroti persoalan yang sesungguhnya merupakan akibat itu lahir. Nasaruddin menandaskan fenomena gender ini mengindikasikan bahwa pemahaman agama (teologi) merupakan sebab utama (prima causa) dalam melahirkan berbagai persepsi yang bias gender. ${ }^{10}$

Di dalam Islam ada beberapa isu kontroversial berkaitan dengan relasi gender, antara lain soal asal usul penciptaan perempuan, konsep kewarisan, persaksian, poligami, hak-hak reproduksi, hak talak, serta peran publik perempuan. Memang membaca sepintas teks ayat-ayat yang berhubungan dengan masalah tersebut mengesankan adanya ketimpangan (ketidakadilan) terhadap perempuan.

Akan tetapi, Nasaruddin memaparkan, jika disimak secara mendalam dengan menggunakan metode analis semantik, semiotik, hermeneutik dan dengan memperhatikan teori sabab nuzul, maka dapat dipahami ayat-ayat tersebut merupakan suatu proses dalam mewujudkan keadilan secara konstruktif di dalam masyarakat. Semua ayat tentang perempuan itu ternyata turun menanggapi kasus-kasus tertentu yang terjadi masa Rasulullah, ini berarti ayat-ayat tersebut bersifat khusus. Selain itu lanjutanya, penafsiran telah diyakini menjadi penyebab utama munculnya bias gender, Nasaruddin juga mengatakan, bahasa Indonesia yang miskin untuk menafsirkan bahasa Arab

\footnotetext{
${ }^{10}$ Nasaruddin Umar, Qur'an untuk Perempuan, hlm. 27.
} 
jug menjadi faktor besarnya toleransi konsep poligami yang menjadi sorotan kontroversial dalam ajaran Islam, dengan jernih dipaparkan oleh Nasaruddin sebagai sebuah kemustahilan yang juga disebutkan oleh al-Qur'an.

Segala sesuatu di muka bumi juga merupakan ayat ini pun menginspirasikan tidak adanya poligami. "Pasangan makrokosmos itu tak ada yang berpoligami, satu siang dan malam. Menurut al Qur'an tidak mungkin seseorang itu bisa berlaku adil pada perempuan (isteri). Dan pemustahilan ini ada dalam an Nisa' 129", paparnya. Nasaruddin menyambung, Islam adalah agama manusiawi yang tak sekedar dipahami secara tekstual saja, termasuk konsep poligami ini. Kalaupun Rasulullah berpoligami menurut Nasaruddin bertujuan untuk mematahkan mitos di masa itu yang mendiskreditkan janda dan anak yatim sebagai manusia sial dan pantas dijauhi. Perempuan yang dinikahi Rasulullah di usia senjanya ini adalah janda-janda veteran perang Uhud dan lainnya yang juga menjadi pemimpin kabilah-kabilah. "Pernikahan ini juga untuk mempertahankan eksistensi Islam sebagai strategi penyiaran dakwah Nabi, sebab dengan mitos berkembang, kehadiran janda dan anak yatim yang jumlahnya meningkat setelah peperangan terancam menjadi murtad." Poligami itu harus dipahami dari hasil pembacaan ayat secara mendalam, bukan sekedar selera saja. ${ }^{11}$

Sementara itu, Menteri Agama Said Agil Husain al-Munawar memaparkan, meskipun al-Qur'an adalah kebenaran abadi, namun penafsirannya tidak bisa terhindar dari sesuatu yang relatif. Perkembangan historis berbagai madzhab kalam, fiqih dan tasawuf merupakan bukti positif tentang betapa relatifnya penghayatan keagamaan umat Islam. pada suatu kurun, kadar inteletualitas yang menonjol, sementara pada kurun lainnya, kadar emosionalitas yang menonjol. Itulah sebabnya mengapa persepsi tentang perempuan di kalangan umat Islam sendiri juga berubah-ubah. ${ }^{12}$

Said Agil mengatakan, pandangan yang menyatakan Adam terlempar dari surga karena ulah Hawa tidak lain hanyalah konspirasi untuk memudahkan perempuan. Al-Qur'an berusaha meluruskan pandangan-

\footnotetext{
11 Ibid. hlm. 30.

${ }^{12}$ www.republikaonline.com, diakses 27 Januari 2014.
} 
pandangan seperti itu yang banyak dipengaruhi cerita-cerita isra'iliyat yang berasal dari kitab tauhid, dimana perempuan digambarkan sebagai obstinator (pembangkang) dan templator (penggoda). Juga dipengaruhi pandangan Kristen lama yang mengidealkan laki-laki dengan menghubungkannya dengan Tuhan (Bapak) dan Yesus Kristus (Tuhan anak: laki-laki). Sedangkan di sisi ain, tafsir ayat-ayat tentang perempuan sangat dipengaruhi ceritacerita isra'iliyat yang bisa jadi sengaja dimasukkan oleh orang-orang yang dahulunya beragama Yahudi dan kemudian masuk atau sengaja disusupkan ke dalam tradisi Islam. ${ }^{13}$ Di sini, ayat al-Qur'an yang menjelaskan tentang persamaan kedudukan dalam hukum dan bebas dari praduga diterangkan dalam surat al-Nisa' ayat 58 :

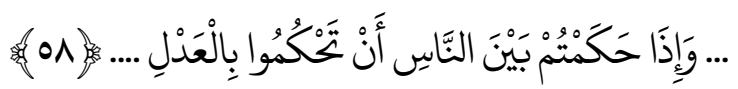

"... dan (menyuruh kamu) apabila menetapkan dengan adil". (QS. al-Nisa' [4]: 58)

Kemudian hadits Rasulullah yang berbunyi:

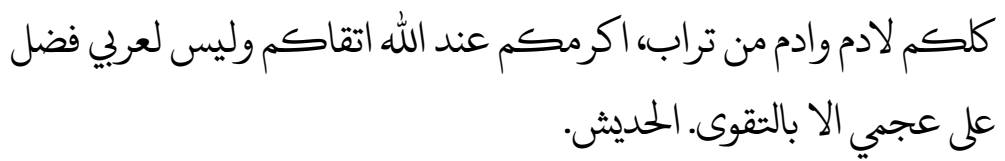

"Kalian semua adalah anak Adam, yang tercipta dari debu. Sungguh yang termulia di antara kalian di sisi Allah adalah yang paling bertaqwa di antara kalian. Tiada lebih utama orang Arab atas orang ajam (ras selain Arab), kecuali yang utama adalah yang bertaqwa." ${ }^{14}$

Nasaruddin dalam argumen kesetaraan gender lebih mengkritisi lagi dalam memberikan analisis. Dengan analisis linguistik, dia menjelaskan bahwa kata nafs, yang terulang 295 kali dalam al-qur'an dengan berbagai bentuknya, tidak satu pun yang dengan tegas menunjuk kepada pengertian Adam. Kata nafs, dalam al-Qur'an kadang berjiwa nafsu, nyawa/ruh, dan hlm. 41.

${ }^{13}$ Sisters in Islam, Are Women and Men Equal Before Allah? SIS Forum, Malaysia, 1991,

${ }^{14}$ Baharuddin Lopa, Al-Qur'an dan Hak-hak Asasi Manusia, hlm. 31-32. 
asal-usul binatang. Analisis ini juga dipakai Baidan dalam tafsir bi al-ra'yi. Dengan bahasa yang lugas di ujung analisisnya dia menyimpulkan bahwa wanita menurut al-Qur'an bukan diciptakan dari tulang rusuk Adam, melainkan dari unsur yang sama dengan Adam, yaitu tanah. ${ }^{15}$

Gender itu sendiri adalah pandangan atau keyakinan yang dibentuk oleh masyarakat tentang bagaimana seharusnya seorang perempuan atau laki-laki dalam bertingkah laku maupun berpikir. Di dalam al-Qur'an disebutkan bahwasanya al-Qur'an tidak mengenal pembedaan antara laki-laki dan perempuan dan yang membedakan antara laki-laki dan perempuan hanyalah dari segi biologisnya. Al-Qur'an tidak mengajarkan diskriminasi antara laki-laki dan perempuan sebagai manusia. konstruk sosial dan agama mendudukkan perempuan pada tempat semestinya, sama halnya dengan membongkar habis sejarah manusia yang telah berlangsung berabad-abad dan yang digugat tidak hanya sistem sosial yang terdiri dari kaum pria, tapi juga dari kaum perempuan itu sendiri.

\section{Simpulan}

Pandangan yang menyatakan bahwa Islam telah mendeskriditkan kedudukan perempuan di bawah laki-laki merupakan suatu hal yang tidak dapat diterima. Munculnya perbedaan kedudukan antara laki-laki dan perempuan lebih banyak disebabkan adanya pemahaman keliru dari keberadaan teks suci al-Qur'an dan adanya konstruksi sosial wasyarakat yang menginterpretasikan teks suci al-Qur'an secara tekstual. Islam melalui alQur'an tidak mengajarkan diskriminasi antara laki-laki dan perempuan sebagai manusia. Konstruk sosial dan agama mendudukkan perempuan pada tempat semestinya, sama halnya dengan membongkar habis sejarah manusia yang telah berlangsung berabad-abad dan yang digugat tidak hanya sistem sosial yang terdiri dari kaum pria, tapi juga dari kaum perempuan itu sendiri. Hal mendasar yang menjadi pembeda antara kaum laki-laki dan perempuan menurut Islam adalah terletak pada kualitas iman dan takwanya.[]

\footnotetext{
${ }^{15}$ Islah Gusmian, Khazanah Tafsir Indonesia..., hlm. 305.
} 


\section{Daftar Pustaka}

Faqih, Mansour, Transformasi Gender, Yogyakarta: LKiS, 2000.

Gusmian, Islah, Khazanah Tafsir Indonesia dan Hermeneutika Hingga Ideologi, Jakarta: Teraju, 2003

Halliday. M.A.K. dan Ruqaiya Hasan, Bahasa, Konteks, dan Teks, Aspek-Aspek bahasan dalam Pandangan Semiotik Sosial, Yogyakarta: Gadjahmada University Press, 1994.

http://www.sekitarkita.com, diakses 24 Pebruari 2014.

http://www.sekitarkita.com/artikekerasan-perempuan-anak.2004.1.html, diakses 15 Januari 2014.

Kekerasan Terhadap Perempuan Bentuk Sebuah Patriarki, 15 Januari 2014, Lihat dalam http://www.sekitarkita.com.

Lopa, Baharuddin, Al-Qur'an dan Hak-hak Asasi Manusia, Yogyakarta: Dana Bhakti Prima Yasa, 1996.

Munir, Lily Zakiyah, Memposisikan Kodrat Perempuan dan Perubahan dalam Perspektif Islam.

Pulitzer, Josept, Sciend and Communication, (terj), Bandung: Citra Aditya Bakti, 2001.

Purwandari, Kristi E., Kekerasan Terhadap Perempuan: Tinjauan Psikologis Feminis, dalam Pemahaman Bentuk-bentuk Kekerasan terhadap Perempuan dan Alternatif Pemecahannya, Editor Archie., 2002.

Sisters in Islam, Are Women and Men Equal Before Allah?, SIS Forum, Malaysia, 1991.

Smith, Margaret, Rabiah Pergulatan Spiitual Perempuan,Risalah Gusti, Surabaya, 1997.

Thahir, Mursyidah (ed.), Pemikiran Islam tentang Pemberdayaan Perempuan, PP Muslimat NU Kerjasama dengan Logos Wacana Ilmu, 2000.

Umar, Nasaruddin, Qur'an Untuk Perempuan, Jaringan Islam Liberal (JIL) dan Teater Utan Kayu, 2002.

www.republikaonline.com, diakses 17 Januari 2014. 